DOI: https://doi.org/10.24144/2409-6857.2019.2(54).61-70

УДК: 316.3 : 353.2 : 005.591 .3

\author{
Переверзсва А.В
}

\title{
ОЦІНКА РОЗВИТКУ ТЕРИТОРІАЛЬНИХ ГРОМАД ЯК СОЦІАЛЬО-ЕКОНОМІЧНИХ СИСТЕМ
}

\begin{abstract}
У статті досліджено поняття складної сочіально-економічної системи та ї̈ властивості. На основі використання когнітивного аналізу виокремлено три типи громад та побудовано когнітивні карти, котрі визначають зв'язок між показниками розвитку. Концептуальні карти побудовано на основі трьох моделей зв'язків між концептами: зі слабкими когнітивними зв'язками; із середніми когнітивними зв'язками; із сильними когнітивними зв'язками. Для побудови когнітивних карт згруповано та ідентифіковано елементи концептів розвитку сочіально-економічної системи «Громада» за єдиним принципом та визначено три концепти «Трудові ресурси», «Інвестиціï», «Бюджет». Обгрунтовано, щчо для громад характерним є слабкий зв'язок між концептами, який визначається значною кількістю зв 'язків між елементами концептів, але за якістю - значення цих показників є низькими.
\end{abstract}

Ключові слова: об'єднані територіальні громади, розвиток, сочіально-економічна система, когнітивні карти, концепт, кореляційний аналіз

Постановка проблеми. В умовах значного впливу новітніх регіональних та глобальних чинників, які дозволяють виокремити особливості та пріоритети розвитку людських та трудових ресурсів, визначити ключові напрями реформування необхідно здійснити аналіз стану та рівень соціально-економічного розвитку об’єднаних територіальних громад.

Громада як соціально-економічна система являє собою сукупність елементів, кожен яких відображає певний аспект розвитку. Одними із найважливіших напрямів функціонування громади є фінансова складова, котра визначається на основі стану бюджету територіального утворення, людські ресурси, які є не лише статтею витрат у бюджеті, але й здатні підвищити рівень самодостатності за рахунок акумуляції свого потенціалу та його раціонального використання. Інвестиційні ресурси громади представлені інвестиційними проектами, реалізація яких розширюе можливості громади та сприяе розширенню простору іiі функціонування за межі територіального утворення. Безумовно усі складові громади як системи є взаємопов'язаними між собою, їх спільна взаємодія створює потенціал територіального утворення, міцність та стійкість якого залежить від сили та характеру зв'язку між елементами громади. У зв'язку із цим питання щодо оцінки розвитку територіальних громад як соціально-економічних систем на основі аналізу взаємозв'язку між елементами є актуальним 3 точки зору визначення «слабких

(C) Переверзсва А.В., к.е.н., доцент кафедри міжнародної економіки, природних ресурсів та економіки міжнародного туризму, Запорізький національний університет, м. Запоріжжя місць» та орієнтирів розвитку територіального утворення.

Аналіз останніх досліджень і публікацій. Важливим науковим обгрунтуванням поняття «складні системи» $є$ трактування Г. Гакена, засновника «синергетики», котрий зазначає, що «складні системи можливо описати, як такі, котрі складаються зі значної кількості складових елементів або компонентів, які можуть мати подібну структур або бути різнорідними. Усі залуженими взаємозв'язками. Існує багато прикладів утворення складних систем, функціонування та розвиток яких досліджується різними науковими галузями. Існують прості та ускладнені за структурою системи. До другого типу належать соціально-економічні системи, які характеризуються ускладненими взаємозв'язками між складовими частинами [1, с. 18].

Практичне застосування методів синергетики в соціальних науках запропонував В. Вайдліх, який зазначає: «Здається очевидним, що реальність, включаючи одушевлений i неодушевлений світи (живу і неживу природу) розділена на шари (стратифікована) 3 різним ступенем організованості. Вищі, більш макроскопічні шари $\epsilon$ складними, i тому «розташовуються над» нижчими, мікроскопічними шарами. Якщо організаційна структура шару така, що йому як цілому властиві якісно нові характеристики, котрих немає в нижчих шарах, то прийнято визначати такий шар як систему. Система - «це більше ніж просто сума iï складових», які не є ознаками частин, а тільки системи як цілого» [2, с. 30-31].

Важливим науковим дослідженням B. Вайдліха $з$ точки зору практичного застосування $\epsilon$ обгрунтування значної «низхідної» взаємодії 
«ціле-частини». Вчений зазначає, що «колективне поле» значно впливає на можливу поведінку індивіда через формування певних орієнтирів та формування традицій i культури на основі взаємодії. Практична реалізація взаємодії між цілим та частинами забезпечується на основі розширення доступу до інформаційних ресурсів, прийняття рішень на основі вже сформованої структури суспільства, за рахунок активізації латентних здібностей людини, котрі можуть виявлятися лише за умови створення певного середовища [2, с. 32, с. 37-38].

Важливими властивостями соціальноекономічної системи є ऑii життєздатність та самодостатність. На думку Р. Ешбі [3] під життєздатністю слід розуміти здатність системи долати невизначеність існування. Дослідник C. Бip [4] виокремив типи життєздатних підсистем та обгрунтував, що кожна життєздатна система повинна мати індивідуальність.

Життєздатність економічних систем досліджувалась в працях таких українських науковців, як: Мадих А.А. [5], Мартиненко В.П. [6], Овечко А.В., Петренко В.Л., Тимохин В.Н. [7], Сергєєва Л.Н., Бакурова Г.В. [8], Шпілєвський В.В. [9] та інші.

Значний внесок у вивченні питань, що стосуються специфіки самодостатності соціально-економічних систем здійснили такі науковці: Заблоцький Б. [10], Молодожен Ю. Б. [11], Морозюк Н. В. [12], Уманець Т. В. [13], Шаталова Л. С. [14] та інші.

Питаннями управління програмами розвитку систем займалися Бушуєв С.Д, Ярошенко Р.Ф., Ярошенко Т.О. Вчені розглядають багатовекторне управління, що забезпечує збалансованість, стратегічну орієнтацію та досягнення ефективних результатів розподілу фінансових коштів [15].

На сучасному етапі значну увагу приділено дослідженню особливостей функціонування та розвитку соціально-економічних систем. Серед науковців необхідно виокремити ТананЛала О. [16], який визначає теоретикометодологічні засади та концептуальні основи соціально-економічних систем. Для визначення особливостей соціально-економічної системи вчений аналізує функціонування споживчої кооперації.

Колектив науковців - О. В. Панухник, В. Я. Кудлак, Н. Ю. Мариненко, І. Ю. Крамар [17] виокремлює важливі проблеми, пов'язані 3 основними критеріями функціонування соціальних-економічних систем в умовах підвищення рівня відкритості національної економіки
Питання стратегічного управління конкурентоспроможністю соціальноекономічними системами на основі використання системного підходу представлено у дослідженнях Мошака С.М., Мікловда В.П., Шандор Ф.Ф., Кубіній Н.Ю., Кубіній В.В. [18].

Серед прикладних досліджень визначеної проблематики необхідно відзначити дослідження Ваклюка Я. [19], який запропонував метод моделювання соціально-економічних систем i розрахунок їх динамічних показників на основі аналогій

Разом $з$ тим, слід зазначити, що питання оцінки оцінка розвитку об'єднаних територіальних громадах як соціально-економічних систем потребує додаткового дослідження i обгрунтування.

Формулювання цілей статті. Метою статті $\epsilon$ оцінка розвитку об'єднаних територіальних громадах як соціально-економічних систем задля визначення «слабких місць» та орієнтирів розвитку територіального утворення.

Опис основного матеріалу дослідження. Значна кількість теоретичних i практичних досліджень щодо функціонування та розвитку складних соціально-економічних систем підтверджує зацікавленість науковців до цієї проблематики. Для того, щоб забезпечити життедіяльність та самодостатність соціальноекономічної системи необхідно здійснити оцінку iii розвитку на основі використання певних моделей, котрі дозволяють не лише визначити потенціал громад, але й об'єднати їх в пені групи 3 метою розробки механізму вдосконалення політики управління та підвищення рівня розвитку. У науковій літературі представлена значна кількість способів аналізу територіальних утворень [20], котрі різняться застосуванням певного набору факторів для здійснення типологізації територіальних утворень. Зазначимо, що існуючі способи для групування пропонують розглядати у комплексі низку факторів, які відповідають за певний напрям розвитку територіальних утворень - економічної, соціальної та інших.

Оскільки об'єднані територіальні громади є складними регіональними підсистемами, то поряд i3 кількісними індикаторами ефективності функціонування громади важливим $\epsilon$ врахування тісноти зв'язку між цими показниками. Як приклад, можна розглянути ланцюг показників діяльності громади, із кінцевим елементом зайнятість в об'єднаній територіальній громаді, котру можна виміряти показником ефективності використання трудових ресурсів. Цей індикатор безпосередньо пов'язаний із такими показниками, 
як обсяг власних доходів, кількість інвестиційних проектів, зайнятість за видами економічної діяльності тощо. Отже, для того, щоб збільшити рівень зайнятості в об'єднаних територіальних громадах, потрібно здійснити певні заходи організаційно-економічного спрямування в ланцюзі взаємопов'язаних факторів, які ведуть до зміни показника зайнятості. Зауважимо, що існування ланцюгів, що мають слабкий зв'язок, призводить до того, що сила імпульсів у вигляді заходів економічного, організаційного впливу та інших, зменшується, суттєво знижуючи ефективність останніх. Навпаки, якщо усі ланцюги громади мають тісний зв'язок, то ефективність заходів, спрямованих на розвиток регіону, суттєво зростає, значно прискорює отримання економічного, соціального, організаційного та інших ефектів.

Відсутністю чи наявністю зв'язків між показниками системи громади можна пояснити таке явище, за якого громада, маючи високі показники розвитку й залучивши значну кількість трудових ресурсів, не отримує очікуваного економічного ефекту, або отримає, але через дещо більший проміжок часу, ніж планувалось. Поряд із тим об'єднані територіальні громади з гіршими показниками розвитку отримують кращі результати за більш короткий проміжок часу.

Отже, пріоритетним стає завдання виявлення ступеня щільності зв'язків між показниками системи «Громада» як соціально-економічного утворення регіональної підсистеми.

Застосування когнітивного підходу може стати одним із найбільш продуктивних для вирішення поставленого завдання. Когнітивний підхід $€$ актуальним, якщо об'єкт управління та його зовнішнє середовище $є$ комплексом складних процесів і чинників, які впливають один на одного. Методологія когнітивного моделювання призначена для аналізу та прийняття рішень у недостатньо визначених ситуаціях [21-23].

Систему «Громада» можна вважати складною для застосування звичайних методів аналізу, тому що вона характеризується певними властивостями (табл. 1).

\section{Властивості громади як складної системи *}

Таблиця 1

\begin{tabular}{|c|c|}
\hline Властивість & Зміст \\
\hline Нестабільність & $\begin{array}{l}\text { Рівень нестабільності зовнішнього соціально-економічного та політичного } \\
\text { середовища для системи «Громада» визначається на основі ситуацій, прогнозів } \\
\text { щодо темпу змін, можливостей передбачити майбутні тенденції. Можливість } \\
\text { передбачення залежить від мінливості чинників, а також темпів і напрямів } \\
\text { розвитку самого середовища. При цьому значний рівень невизначеності та } \\
\text { нестабільності екзогенних чинників, уповільнює та ускладнює процес } \\
\text { прийняття тактичних і стратегічних рішень. }\end{array}$ \\
\hline Слабкоструктурованість & $\begin{array}{l}\text { Складнощі аналізу процесів та прийняття управлінських рішень у таких } \\
\text { галузях, як економіка, соціологія тощо, зумовлені низкою особливостей, } \\
\text { властивих цим галузям, а саме: багатофакторністю процесів, що відбуваються } \\
\text { в них (економічних, соціальних тощо) та їх взаємовпливом; неможливістю } \\
\text { виокремлення й детального дослідження окремих явищ-усі процеси та явища, } \\
\text { характерні для них, повинні аналізуватися комплексно; відсутністю необхідної } \\
\text { інформації щодо динамічності процесів; мінливим характером процесів та } \\
\text { явищ } 3 \text { точки зору часового критерію тощо. Визначені особливості } \\
\text { обумовлюють слабку структурованість економічних, соціальних та інших } \\
\text { подібних систем. Отже, на відміну від технічних систем, економічні, } \\
\text { соціально-політичні та інші аналогічні системи характеризуються відсутністю } \\
\text { детального кількісного опису процесів, які відбуваються в них, - інформація, } \\
\text { переважно, має якісний характер. Тому для слабкоструктурованих систем } \\
\text { неможливе створення формальних традиційних кількісних моделей. Для } \\
\text { систем подібного типу характерні невизначеність, опис на якісному рівні, } \\
\text { неоднозначність оцінки наслідків тих чи інших рішень. }\end{array}$ \\
\hline
\end{tabular}

*Джерело: Складено автором за даними [24]

Враховуючи властивості громади як системи, виокремлені в таблиці 1, зауважимо, що ефективним інструментарієм дослідження слабкоструктурованого середовища, яке характеризується значним рівнем нестабільності,
$€$ когнітивний аналіз. Когнітивний підхід дозволяє виокремити та 3'ясувати сутність проблем, які виникають у середовищі, виявити протиріччя та здійснити якісний аналіз усіх процесів i явищ. Когнітивне моделювання - 
ключовий момент когнітивного аналізу, суть якого полягає у висвітленні найскладніших проблем i тенденцій розвитку регіональної системи у вигляді спрощеної ідеалізованої моделі, дослідженні можливих сценаріїв виникнення кризових явищ, пошуку шляхів та умов їх вирішення [24].

Типологізація об'єднаних територіальних громад на основі когнітивного моделювання поєднує п'ять етапів. Етапи когнітивного підходу до аналізу об'єднаних територіальних громад $\epsilon$ такими:

1) Когнітивна структуризація громади передбачає трьох підконцептосфер концептосфери «Громада»: «Трудові ресурси»; «Бюджет»; «Інвестиції».

Підконцептосфера «Трудові ресурси» нараховує вісім концептів: рівень середньої заробітної плати; зайнятість населення; рівень безробіття; відсоток зайнятості у сільському господарстві; відсоток зайнятості у виробничий сфері; відсоток зайнятості у торговообслуговуючій сфері; кількість підприємств сільськогосподарського спрямування; кількість промислових підприємств.

Підконцептосфера «Бюджет» нараховує п’ять концептів: доходи бюджету на одну особу; власні доходи на одну особу; регульовані доходи на одну особу; витрати бюджету на одну особу; дефіцит/профіцит бюджету.

Підконцептосфера «Інвестиції» нараховує два концепти: кількість інвестиційних проектів, запропонованих громадою; загальна орієнтовна вартість інвестиційних проектів (власні можливості, допомога держави, взаємодопомога громад).

б) Структурний аналіз когнітивної моделі передбачає встановлення наявності чи відсутності зв'язків між обраними концептами в межах концептосфері «Громада».

Скористаємось методом сценарного моделювання когнітивної карти підконцептосфери громади, який полягає у зміні значень показників концептів та дослідженні у цьому зв'язку змін у функціонуванні усієї системи. За результатами отриманих значень зв'язків між концептами когнітивної карти (результатами сценарного моделювання) здійснюємо оцінку діяльності громади, ранжування з іншими громадами, віднесення іiі до громади 3 певним ступенем розвитку трудових ресурсів.

Доцільно, на нашу думку, виконувати розподіл громад за трьома типами: громади зі слабкими когнітивними зв'язками, громади 3 середніми когнітивними зв'язками, громади 3 сильними когнітивними зв' язками:

Розглянемо кожний із наведених типів громад окремо.

Громади зі слабкими когнітивними зв'язками. До цього типу громад відносяться ті, зв'язок між концептами яких знаходиться переважно в діапазоні числових значень від $-0,4$ до +0,4. Сценарне моделювання в громадах такого типу виявляє результати передачі слабких імпульсів між концептами. Отже, стандартні заходи щодо підвищення ефективності діяльності громади виявляються малоефективними. Громада потребує суттєвого втручання економікоорганізаційного спрямування, особливо в концепти 3 найменшими показниками ступеня зв'язків.

Громади із середніми когнітивними зв'язками. До цього типу громад відносяться ті, зв'язок між концептами яких перебуває переважно в діапазоні чисел від -0,4 до -0,8 і від $+0,4$ до $+0,8$. Сценарне моделювання в громадах такого типу вказує на результати передачі імпульсів середньої сили між концептами. Це означає, що громада працює більшою мірою ефективно, при наявності проблемних місць. Громада потребує втручання економіко-організаційного спрямування в концепти 3 найменшими показниками ступеня зв'язків.

Громади 3 сильними когнітивними зв'язками. До цього типу громад належать такі, зв'язок між концептами яких знаходиться переважно в діапазоні чисел від $-0,8$ до -1 і від $+0,8$ до +1 . Сценарне моделювання в громадах такого типу вказує на результати передачі сильних імпульсів між концептами. Це означає, що громада працює достатньо ефективно, проблемні місця відсутні, або незначні. Як і у випадку 3 регіонами 3 середнім ступенем когнітивних зв'язків, громада потребує втручання економіко-організаційного спрямування в концепти 3 найменшими показниками ступеня зв'язків, але ефективність від таких заходів буде значно вищою. За рахунок наявності сильних зв'язків між концептами громад такого типу вони $\epsilon$ найбільш привабливими для запровадження нових технологій, відкриття нових галузей, впровадження комп'ютеризованих систем управління тощо.

На основі описаного когнітивного підходу до побудови моделі розвитку було проведено аналіз об'єднаних територіальних громад: Малотокмачанська, Остриківська, Берестівська та Преображенська сільські громади Запорізької області. Визначено коефіцієнти кореляції між показниками концептів (табл. 2-табл. 3). 
Таблиця 2 Статистичні дані для кореляційного аналізу показників підконцепту «Трудові ресурси»

\begin{tabular}{|c|c|c|c|c|c|c|c|c|}
\hline \multirow[t]{2}{*}{ Громади } & \multicolumn{8}{|c|}{ Підконцепт «Трудові ресурси» } \\
\hline & 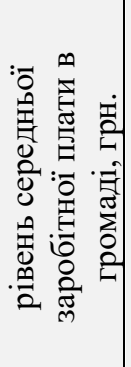 & 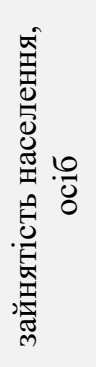 & 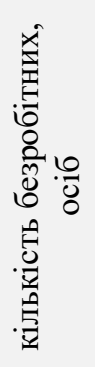 & 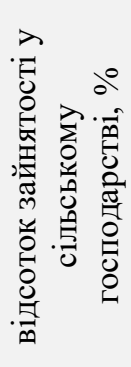 & 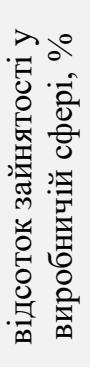 & 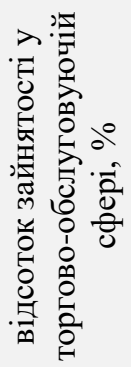 & 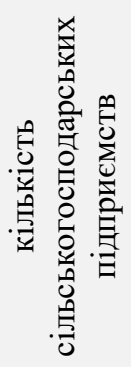 & 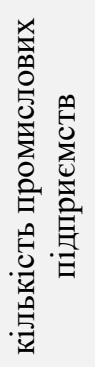 \\
\hline 1 & 2 & 3 & 4 & 5 & 6 & 7 & 8 & 9 \\
\hline $\begin{array}{l}\text { Берестівська } \\
\text { сільська }\end{array}$ & 1830 & 618 & 278 & 51 & 0 & 49 & 8 & 0 \\
\hline $\begin{array}{l}\text { Малотокмачанська } \\
\text { сільська }\end{array}$ & 2100 & 997 & 449 & 15 & 7 & 78 & 3 & 2 \\
\hline $\begin{array}{l}\text { Остриківська } \\
\text { сільська }\end{array}$ & 4800 & 596 & 1204 & 43 & 16 & 41 & 5 & 1 \\
\hline $\begin{array}{l}\text { Преображенська } \\
\text { сільська }\end{array}$ & 3575 & 3404 & 507 & 83 & 4 & 17 & 5 & 1 \\
\hline
\end{tabular}

Аналіз враховує тільки позитивні значення коефіцієнтів кореляції, що свідчить про наявність прямого зв'язку між показниками окремих підконцептів.
Узагальнення даних кореляційного аналізу показників підконцептів «Трудові ресурси», «Бюджет» та «Інвестиції» побудувати когнітивні карти.

Таблиця 3

Статистичні дані для кореляційного аналізу показників підконцептів «Бюджет» та «Інвестиції»

\begin{tabular}{|c|c|c|c|c|}
\hline \multirow{3}{*}{ Громади } & \multicolumn{2}{|c|}{ Підконцепт «Бюджет» } & \multicolumn{2}{|c|}{ Підконцепт «Інвестиції» } \\
\hline & $\begin{array}{c}\text { доходи } \\
\text { бюджету на } \\
\text { одну особу }\end{array}$ & $\begin{array}{c}\text { витрати бюджету на } \\
\text { одну особу }\end{array}$ & $\begin{array}{c}\text { кількість } \\
\text { інвестиційних } \\
\text { проектів, } \\
\text { запропонованих } \\
\text { громадою }\end{array}$ & $\begin{array}{c}\text { загальна орієнтована } \\
\text { вартість інвестиційних } \\
\text { проектів, млн. грн }\end{array}$ \\
\hline & 1 & 2 & 1 & 2 \\
\hline $\begin{array}{l}\text { Малотокмачанська } \\
\text { сільська громада }\end{array}$ & 1810,1 & 1712,55 & 4 & 16,8 \\
\hline $\begin{array}{l}\text { Остриківська } \\
\text { сільська громада }\end{array}$ & 1723,39 & 1506,07 & 7 & 32,2 \\
\hline $\begin{array}{l}\text { Берестівська } \\
\text { сільська громада }\end{array}$ & 2579,67 & 2525,47 & 8 & 8,3 \\
\hline $\begin{array}{l}\text { Преображенська } \\
\text { сільська громада }\end{array}$ & 3349,23 & 2980,71 & 6 & 7,2 \\
\hline
\end{tabular}

Для побудови когнітивних карт доцільно згрупувати та ідентифікувати елементи концептів

Розвиток соціально-економічної системи «Громада» передбачає виокремлення трьох концептів: трудові ресурси, бюджет та розвитку соціально-економічної системи «Громада» за єдиним принципом (рис. 1).

інвестиції (рис. 2.6). Елементи кожного концепту ідентифікуються відповідним позначенням: Т трудові ресурси, Б - бюджет, I - інвестиції. Кожен 
елемент концепту має змістовну характеристику, наприклад Т1 - рівень середньої заробітної плати в громаді, Б1 - доходи бюджету на одну особу, I1 кількість інвестиційних

проектів,

К О Н Ц Е П Т И

розвитку соціально-економічної системи «Громада»

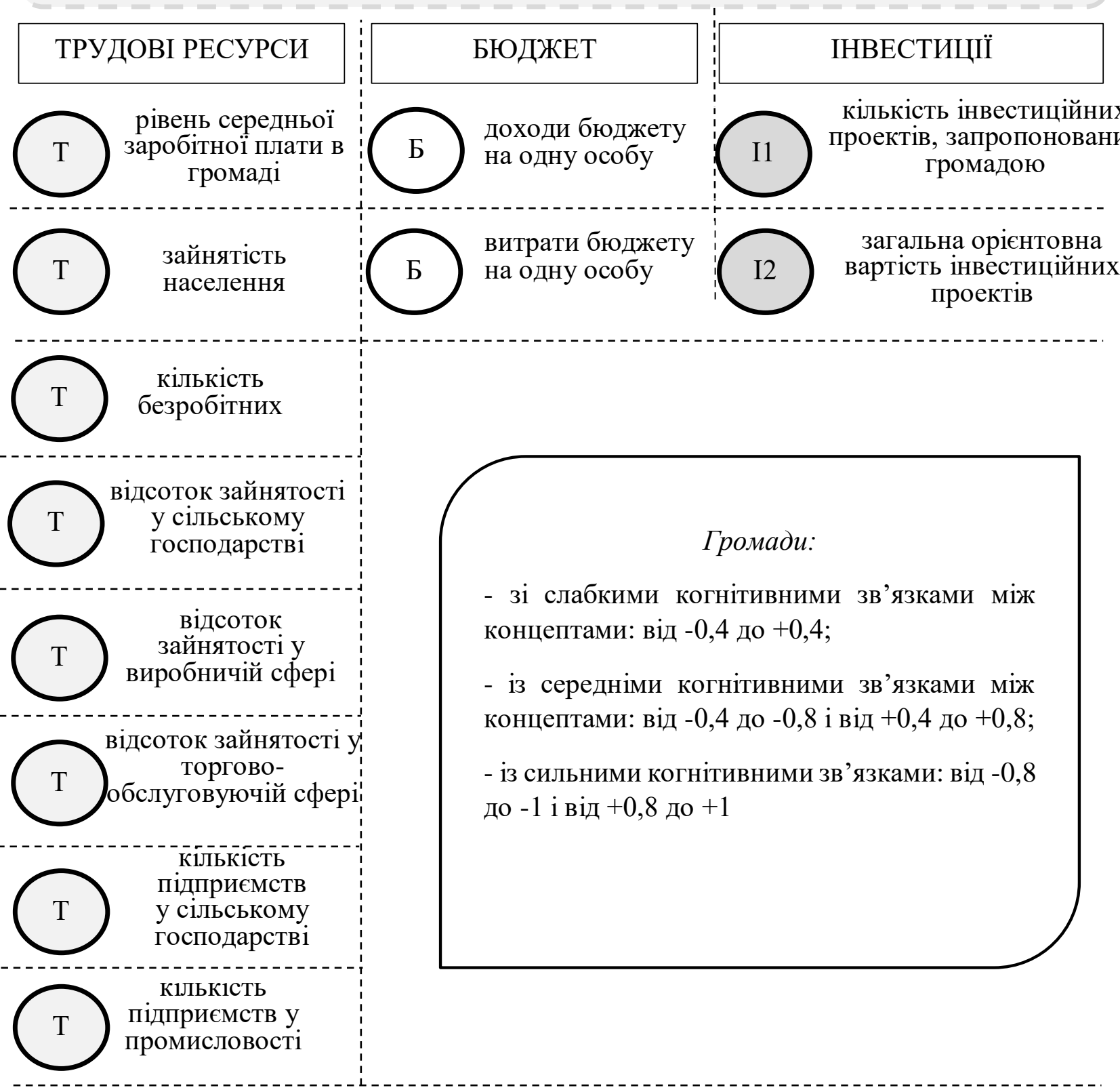

Рисунок 1 - Групування та ідентифікація елементів концептів розвитку соціально-економічної системи «Громада» *

*Джерело: Розроблено автором

Концептуальні карти побудовано на основі трьох моделей зв'язків між концептами:

1) зі слабкими когнітивними зв'язками: від 0,4 до $+0,4$ (рис. 2);
2) із середніми когнітивними зв'язками: від 0,4 до $-0,8$ та від $+0,4$ до $+0,8$ (рис. 3 );

3) із сильними когнітивними зв' язками: від 0,8 до - 1 та від $+0,8$ до +1 (рис. 4 ). 


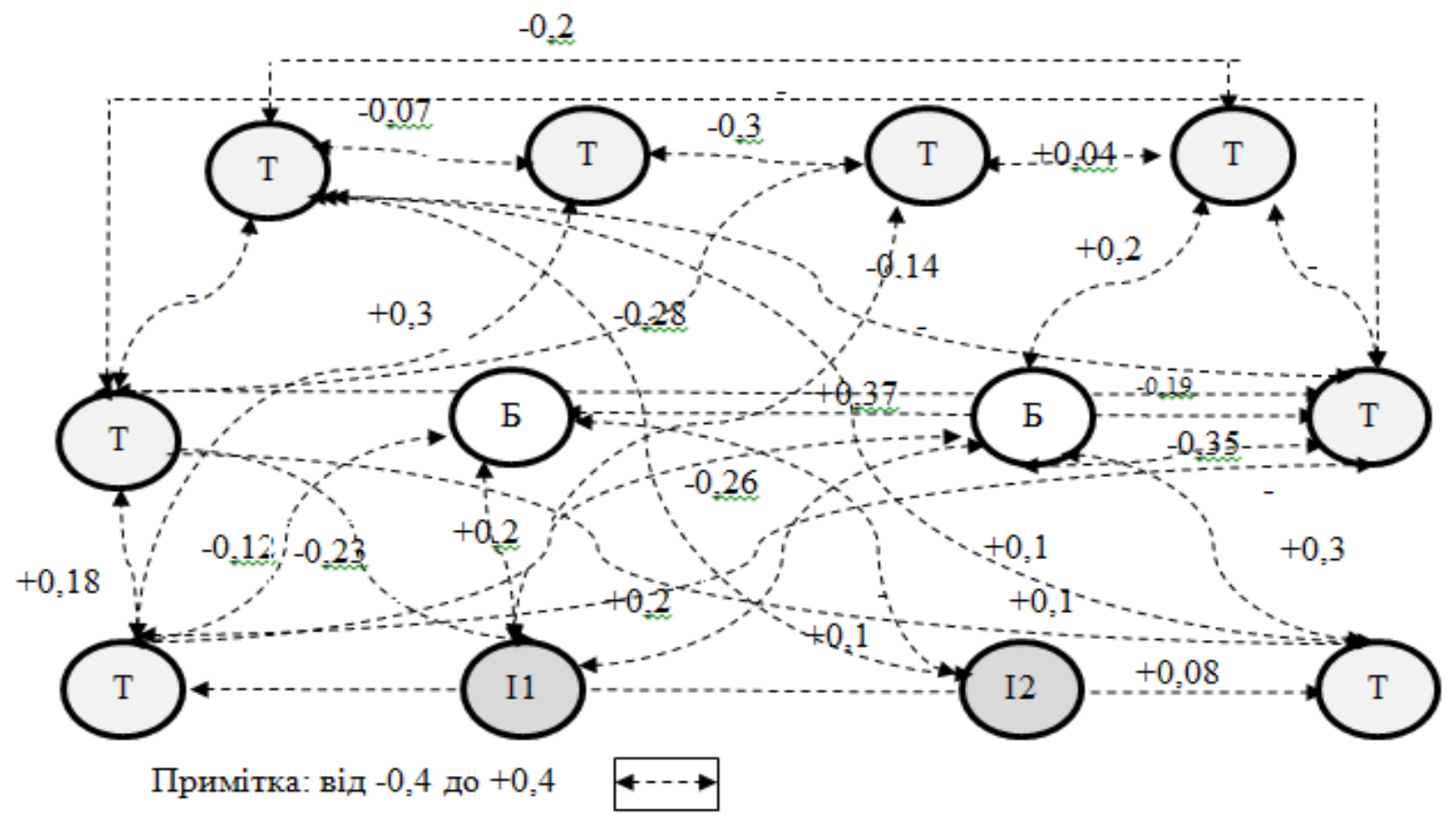

Рисунок 2 - Когнітивна карта зі слабкими когнітивними зв'язками між концептами * *Джерело: Розроблено автором

Когнітивна карта (рис. 3) наочно демонструє концептами, але сила цього зв'язку наявність значної кількості зв'язків між характеризується низькими показниками.

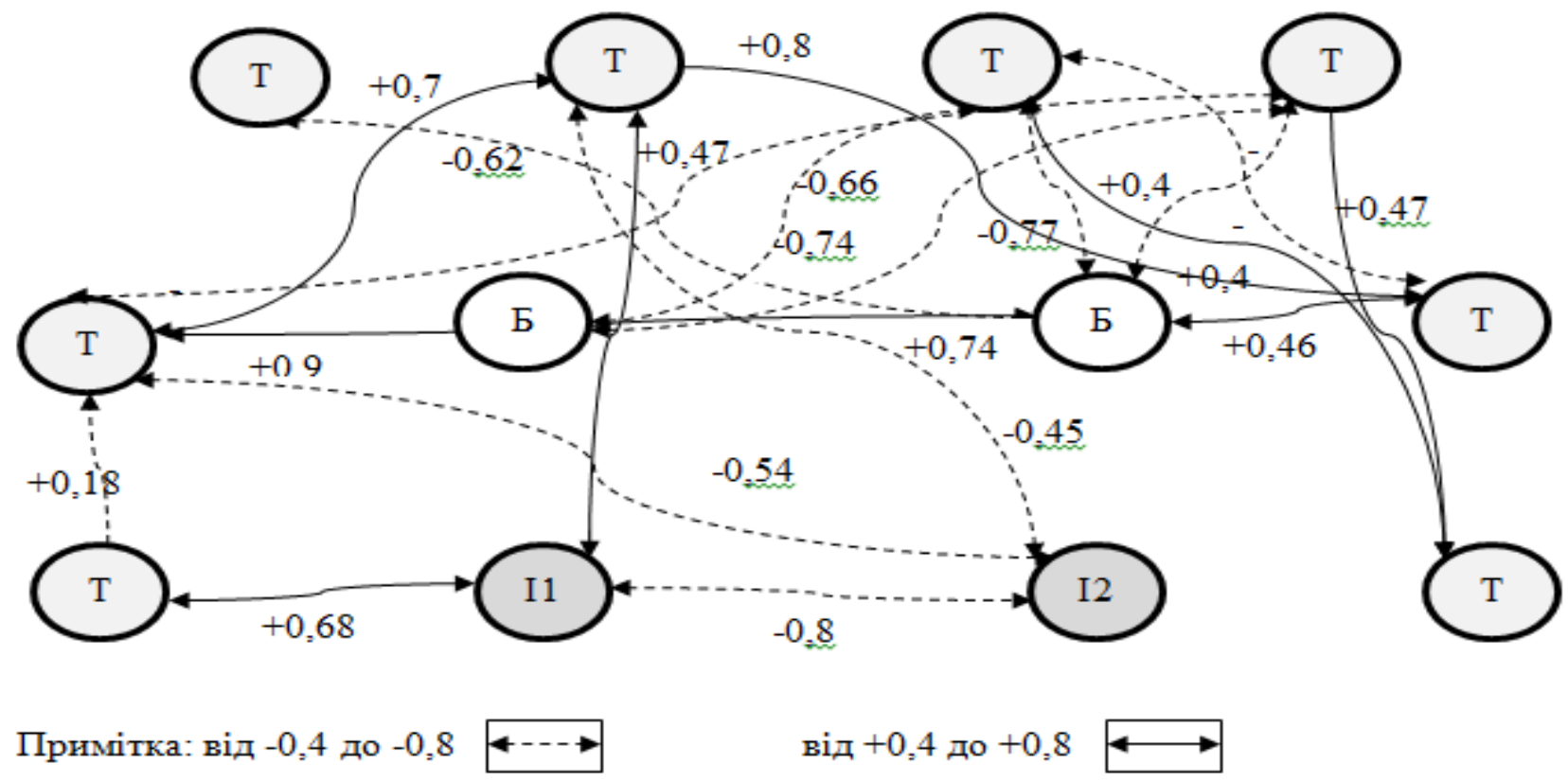

Рисунок 3- Когнітивна карта із середніми когнітивними зв'язками між концептами* *Джерело: Розроблено автором

Когнітивна карта на рис. 4 характеризує наявність помірного зв'язку між елементами концептів. Когнітивна карта із сильними зв'язками (рис. 4) показує найменшу кількість зв'язків між елементами концептів значної сила. 


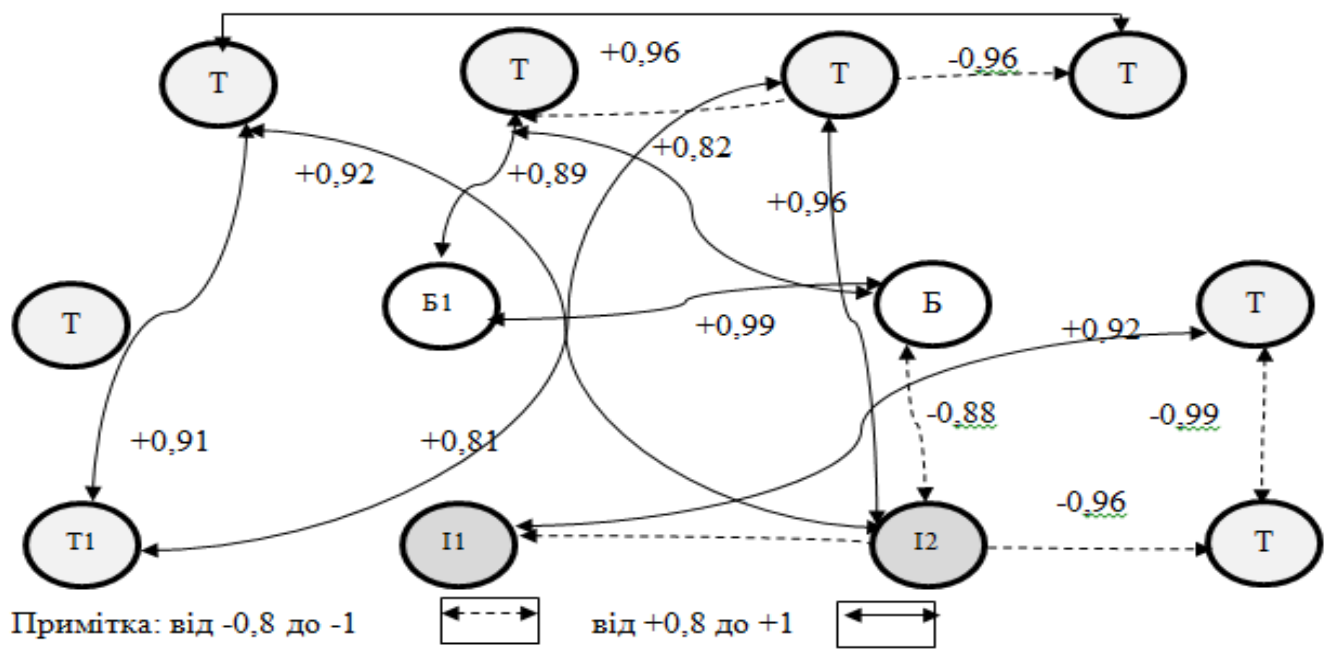

Рисунок 4- Когнітивна карта із сильними когнітивними зв'язками *

*Джерело: Розроблено автором

Аналіз когнітивних карт 2-4 показує, що зв'язок між концептами є слабким. На рис. 2 показана найбільша кількість зв'язків між елементами концептів, але за якістю - значення цих показників $є$ низькими, що підтверджує слабкість зв'язку.

Висновки i перспективи подальших досліджень. Отримані результати свідчать про необхідність розробки нового підходу до визначення умов розвитку трудових ресурсів об'єднаних територіальних громад. В основу покладено не тільки якісну та кількісну оцінки факторів впливу на розвиток громади, але й доповнено силою і характером зв'язків. Отже, ефективність виконання поставленого завдання залежить від раціональності та достовірності використання когнітивного підходу для оцінки темпів розвитку та поточного стану територіальних громад. Когнітивна модель розвитку об'єднаних територіальних громад дозволяє комплексно і грунтовно аналізувати соціально-економічну систему «Громада» та окремі ії підсистеми, встановлювати зв'язки між факторами впливу на розвиток, проводити сценарне моделювання для виявлення «вузьких» місць розвитку громади, спираючись на когнітивні причинно-наслідкові зв'язки в економічній, соціальній та інших системах громади. Наочність результатів розрахунків за цим методом дозволяє приймати управлінські рішення в масштабі реального часу. Такий підхід виводить аналіз розвитку територіальних громад на принципово новий кількісний і якісний рівень, дозволяє приймати обгрунтовані економікоорганізаційні рішення щодо удосконалення внутрішньої політики функціонування як на рівні громади, так і на регіональному та національному рівнях.

Таким чином, напрямком подальших досліджень $\epsilon$ виокремлення конкретних економіко-організаційних заходів та їх обгрунтування для кожного типу громад.

\section{ПЕРЕЛІК ВИКОРИСТАНИХ ДЖЕРЕЛ}

1. Хакен Г. Информация и самоорганизация. Макроскопический подход к сложным системам. М.: КомКнига, 2005. 248 с.

2. Вайдлих В. Социодинамика: системный подход к математическому регулированию в социальных науках: Пер с англ. / Под ред. Ю.С. Попкова, А.Е. Семечкина. - М.: Едиториал УРСС, 2005. $480 \mathrm{c}$.

3. Эшби У.Р. Введение в кибернетику. М.: Наука, 1975. 427 с.

4. Бир С. Мозг фирмы: пер. с англ. М.: Радио и связь, 1993. 416 с.

5. Мадых А.А. Нечеткий подход при моделировании жизнеспособности ПЭС. Модели управления в рыночной экономике : сб. науч. тр. / [общ.ред. Ю.Г. Лысенко; Донецкий нац. ун-т]. Донецк: ДонНУ, 2005. Т. 1: Спец. вып. С. 185-194.

6. Мартиненко В.П. Стратегія життєздатності промислових підприємств: монографія. К.: Центр навчальної літератури, 2006. 328 с. 
7. Овечко А.В., Петренко В.Л., Тимохин В.Н. Модели и методы адаптивной экономики. Донецк: Юго-Восток, Лтд, 2003. $156 \mathrm{c.}$

8. Сергєєва Л.Н., Бакурова А.І. Моделювання структури життєздатності соціально-економічних систем: монографія / та ін. Запоріжжя: Вид-во КПУ, 2009. 200 с.

9. Шпілєвський В.В. Формування фінансової життєздатності коксохімічних підприємств: дис. канд. екон. наук : 08.00.04. Харків, 2007. 179 с.

10. Заблоцький Б. Економічна самодостатність регіону. Регіональна економіка. 2001. № 1. С. 40 53.

11. Молодожен Ю. Б. Самодостатність територіальних громад: системний підхід: монографія. Одеса: ОРІДУ НАДУ, 2010. 370 с.

12. Морозюк Н. В. Теоретичні аспекти самодостатності сільських територіальних громад. Режим доступу: http://www.pdaa.edu.ua/sites/default/files/nppdaa/5.1/173.pdf.

13. Уманець Т. В., Шаталова Л. С. Критерії інтегральної оцінки економічної самодостатності регіону. Режим доступу: http://dspace.oneu.edu.ua/jspui/bitstream/.

14. Шаталова Л. С. Теоретичні основи визначення категорії «самодостатність» як дефініції державного Р управління. дежим доступу до ресурсу: http://dspace.oneu.edu.ua/jspui/handle/123456789/2122.

15. Бушуєв С.Д, Ярошенко Р.Ф., Ярошенко Т.О. Концентрична модель багатовекторного управління програмами розвитку фінансових систем // Управління розвитком складних систем. 2012. №9. C. 14-18.

16. Таран-Лала О. М. Функціонування соціально-економічних систем: теорія та практика : монографія. Полтава : ПУЕТ, 2016. 332 с.

17. Сучасні соціально-економічні проблеми теорії та практики розвитку економічних систем : колективна монографія / та ін. ; відп. ред. О.В. Панухник. Тернопіль : ФОП Осадца Ю.В., 2016. 204 с.

18. Мошак С.М., Мікловда В.П., Шандор Ф.Ф., Кубіній Н.Ю., Кубіній В.В. Стратегічне управління конкурентоспроможністю: системний метод та екзистенціальна експозиція: монографія. Мукачево: Карпатська вежа. 2017. 240 с.

19. Моделювання соціально-економічних систем і розрахунок їх динамічних показників на основі аналогій. Фізико-математичне моделювання та інформаційні технології. 2010. Вип. 11. С. 39-48.

20. Ross D. Economic Theory and Cognitive Science: Microexplanation. The MIT Press, 2007. 454 p.

21. Thagard P. Mind: Introduction to Cognitive Science. Cambridge, MA : The MIT Press, 2005. 153 p.

22. Topol R., Walliser B. Cognitive Economics: New Trends. Elsevier Science, 2007. 278 p.

23. Walliser B. Cognitive Economics. Springer, 2008. 185 p.

24. Axelrod R. The Structure of Decision: Cognitive Maps of Political Elites. Princeton : University Press. 1976. 404 p.

\section{REFERENCES}

1. Haken, H. (2005) Informatsiia i samoorganizatsiia. Makroskopicheskiy podhod k slozhnym sistemam [Information and self-organization. A macroscopic approach to complex systems]. Moscow : KomKniga [in Russian].

2. Weidlich, W. (2005) Sotsiodinamika: sistemnyy podhod k matematicheskomu regulirovaniiu v sotsialnyh naukakh [Sociodynamics: a systematic approach to mathematical modelling in the social sciences]. Moscow : Editorial URSS [in Russian].

3. Ashby, W. R. (1975) Vvedenie v kibernetiku [An introduction to cybernetics]. Moscow: Nauka [in Russian].

4. Beer, S. (1993). Mozg firmy [Brain of the firm]. Moscow : Radio and svyaz [in Russian].

5. Madykh, A. A. (2005) Nechetkiy podhod pri modelirovanii zhiznesposobnosti PES. Modeli upravleniia $\mathrm{v}$ rynochnoy ekonomike [Fuzzy approach to modeling PES viability, Management models in market economy: collection of scientific papers]. DonNU, 1, 185-194 [in Ukrainian].

6. Martynenko, V. P. (2006) Strategiia zhyttiezdatnosti promyslovykh pidpryiemstv [Strategy of industrial enterprises` viability]. Kyiv : Centr navchalnoyy literatury [in Ukrainian].

7. Ovechko, A. V., Petrenko,V.L. \& Timochin, V. N. (2003) Modeli i metody adaptivnoy ekonomiki [Models and methods of the adaptive economics]. Donetsk : Ltd.Yugo-Vostok [in Russian].

8. Sergeeva, L. N. \& Bakurova, A. V. (2009) Modeliuvannia struktury zhyttiezdatnosti socialnoekonomichnykh system [Modelling of socio-economic systems`viability structure]. Zaporizhzhya : Publishing house KPU [in Ukrainian]. 
9. Shpilevskiy, V. V. (2007) Formuvannia finansovoyi zhyttiezdatnosti koksokhimichnykh pidpryiemstv [The creation of coke-chemical enterprise financial viability]. Candidate's thesis. Kharkiv [in Ukrainian].

10. Zabolotsky, B. F. (2001) Ekonomichna samodostatnist regionu [Economic self-efficiency of the region]. Regional economics, 1, 40-53 [in Ukrainian].

11. Molodozhen, Yu. B. (2010). Samodostatnist terytorialnykh gromad: systemnyy pidkhid [SelfSufficiency of Territorial Communities: system approach]. Odessa : ORIDU NADU [in Ukrainian].

12. Morozyuk, N. V. Teoretychni aspekty samodostatnosti silskykh terytorialnykh gromad [Theoretical aspects of self-sufficiency of rural territorial communities]. Retrieved from http://www.pdaa.edu.ua/sites/default/files/nppdaa/5.1/173.pdf [in Ukrainian].

13. Umanets T. V. \& Shatalova, L. S. (2018) Kryteriyi integralnoyi otsinky ekonomichnoyi samodostatnosti regionu [Criteria for the integrated assessment of economic self-sufficiency of the region]. Retrieved from http://dspace.oneu.edu.ua/jspui/bitstream/ [in Ukrainian].

14. Shatalova, L. S. Teoretychni osnovy vyznachennia kategoriyi «samodostatnist» yak definitsiyi derzhavnogo upravlinnia [Theoretical basis for determining the category of "self-sufficiency" as a definition of public administration]. Retrieved from http://dspace.oneu.edu.ua/jspui/handle/123456789/2122 [in Ukrainian].

15. Bushuev, S. D., Yaroshenko, R. F. \& Yaroshenko, T. O. (2012) Kontsentrychna model bagatovektornogo upravlinnia programamy rozvytku finansovyh system [Concentric model of multi-vector management of financial systems development programs]. Management of complex systems` development, 9, 14-18 [in Ukrainian].

16. Taran-Lala, O.M. (2016) Funktsionuvannia socialno-ekonomichnykh system: teoriya ta praktyka [Functioning of socio-economic systems: theory and practice]. Poltava: PUET [in Ukrainian]..

17. Panukhnik, O.V. (2016) Suchasni socialno-ekonomichni problemy teoriyi ta praktyky rozvytku ekonomichnykh system [Modern socio-economic problems of theory and practice of development of economic systems]. Ternopil: FOP Osadtsa Yu.V. [in Ukrainian].

18. Moshak, S.M., Miklovda, V.P., Shandor, F.F., Kubiniy, N.Yu. \& Kubiniy V.V. (2017) Strategichne upravlinnia konkurentospromozhnistiu: systemnyy metod ta ekzystentsialna ekspozytsiia [Strategic competitiveness management: systematic method and existential exposure]. Mukachevo: Karpatska vezha [in Ukrainian].

19. Ваклюка, Я. (2010) Modeliuvannia socialno-ekonomichnykh system i rozrakhunok ykh dynamichnykh pokaznykiv na osnovi analogii [Modeling of socio-economic systems and calculation of their dynamic indicators on the basis of analogies]. Fizyko-matematychne modeliuvanniatfinformatsiyni tekhnologii, 11, 39-48 [in Ukrainian].

20. Ross, D. (2007) Economic Theory and Cognitive Science: Microexplanation. Cambridge : The MIT Press, [in English].

21. Thagard, P. (2005) Mind: An Introduction to Cognitive Science. Cambridge: The MIT Press [in English].

22. Topol, R. \& Walliser B. (2007) Cognitive Economics: New Trends. Elsevier Science [in English].

23. Walliser, B. (2008) Cognitive Economics. Springer [in English] .

24. Axelrod, R. (1976) The Decision Structure: Cognitive Maps of Political Elites. - Princeton: University Press [in English]. 